With Prof. Ayrton I have done for water what Prof. James Thomson did for carbonic acid; we constructed in stiff paper a surface or surfaces which represent the relations of $p, v$ and $t$ for a given quantity of water-stuff. Three parts of the whole are cylindric surfaces and divide space into three regions ; in one of them the substance is in the form of ice, in another in the form of water, in another in the form of vapour; and they meet in Thomson's triple point. Aly one looking at this model must feel that Prof. Ayrton was right in looking for the hot-ice state in a region bounded by imaginary productions of the all-ice, the all-water, the all-vapour, and the above-mentioned three cylindric surfaces beyond their lines of intersection. This is what Prof. James Thomson did to indicate the state of water before boiling by bumping begins. $\mathrm{He}$ assumed that the all-water surface changed into the all-vapour surface gradually, and not through a purely cylindric zeater-vapour surface, and this is really what Dr. Lodge himself does for hot ice. That is, he imagines the all-ice surface to change into the all-vapour surface gradually, and not by sudden changes through a purely cylindric ice-vapour surface. According to Mr. Ayrton the imaginary production is even of a more complicated kind than Dr. Lodge supposes, as the ice probably changes into unstable water before it changes into steam. There can be no doubt that such imaginary productions find their place in the fundamental equation of water, but I cannot agree with Dr. Lodge in thinking that we have at present an explanation of such unstable conditions. If his explanation were satisfactory we onght to be able in the same way to explain the unstable position which precedes boiling by bumping, and this we cannot do. Where the explanation seems to me to fail is in the assumption that the hot vapour filling a cavity, being of lower temperature than the surface of the cavity, is always at a pressure less than that of saturation, in spite of the evaporation going on. Now when we consider bow large the surface of a minute cavity is as compared with its volume, the very great increase in bulk when the solid is changed into vapour and the lowering of temperature which the surface must undergo on account of latent heat, we see that the condition which Dr. Lodge assumes to be maintained during the whole experiment would be instantaneously destroyed in a very minute cavity. In explaining hot ice I am afraid that neither Prof. Ayrton nor Dr. Lodge has given us more than Prof. James Thomson has given in explaining "boiling by bumping." The cause of the phenomenon is a molecular one probably, and must be left to the guesses of molecular physicists.

14, Talgarth Road, West Kensington

\section{Mr. Bottomley's Experiments with Vacuum Tubes and the Aurora}

Mr. BotTomLixy's extremely interesting experiments briefiy described in NATURE, vol. xxiii. pp. 218 and 243 , appear to have a very important bearing on the question of atmospheric electricity ; for if such high vacua are good conductors of electricity we have reason for thinking that the electrical condition of our globe will be very different from what we have been accus. tomed to regard them. The layers of denser air surrounding the conducting matter of the globe will act like the glass of $\mathrm{Mr}$. Bottomley's tubes in maintaining by a Leyden-jar-like action any difference of potential that there may be between their inner and their outer surface. Again, in the piercing of the glass tube by a minute spark, we have the analogue of the lightning flash between the clouds and the earth; the insulating layer in each case giving way, when, owing to an excessive increase in the surface density of the charge at any point, the dielectric stress exceeds the limits of the dielectric strength of the medium. The internal luminous effects observed by $\mathrm{Mr}$. Bottomley as the result of change in the dis'ribution of the external charge of electricity will be the physical analogues of the aurora, with this difference, that they take place in the ultra-gaseous interior, whereas in the case of cur globe the luminous phenomena take place in the ultra gaseous (i.e. highly rarefied) exterior regions of the atmosphere. It would be interesting to learn whether such discharges present any other analogies with auroral phenomena. I should be particularly interested in learning whether the conditions under which such luminous effects are obtained give any support to the theory which I think to be the only consistent one, that the aurora is due not to electrical discharges from regions of less atmospheric density to regions of a greater density (or vice versâ), but to electrical discharges in a region of pretty uniform (and small) density, and in which region differences of electric potential exist. According to this view the auroral streaks which appear to be radial should in reality lie approximately parallel to the earth's surface, and not stand (as most persons imagine) normal to it. A series of hori. zontal parallel lines drawn across the sky in a direction approximately north and south would necessarily appear to an observer on the earth's urface foreshortened into a set of lines diverging in fan-like forms at either the north point or the south point of the horizon. Their divergence would therefore be apparent only, like the "beams" diverging from the sun at sunset on a cloudy day, or like the beams of the rayons du crepuscule, or like the "I adial streaks" which I have pointed out as frequently accompanying rainbows.

\section{University College, Bristol, January 22}

P.S.-The behaviour of a hollow sealed glass tube containing a conducting substance in its interior was noticed just one hundred years ago by Cavallo, who sealed up a glass tube in which mercury was at its boiling-point, thus obtaining a fairly perfect vacuum. -S. P. T.

\section{The Geological Age of the North Highlands of Scottand}

From the abstract of Proceedings of the Geological Society (January 5) I learn with surprise that Sir R. Murchison's interpretation of the succession of the beds over the region north of the Caledonian Canal is disputed, and that the relations of the fossiliferous limestone of Durness to the quartzites "are" (according to Dr. Callaway) "by no means satisfactorily established, and that their conformity is rendered dubious by a marked dicordance of strike" ; in fact that the limestone lies in a synclinal basin am ngst the quartzites, so that if the lime. stone be of Lower Silurian ("Arenig") age the quartzites and schists must be older; this I presume to be the inference Dr. Callaway intends to draw, as he says there "is no proof of the Lower Silurian age of the quartzite and newer series of flaggy gneiss and schist" constituting the interior mountainous district.

Having had an op/3rtunity last spring of visiting the district lying between Lochs Bror $\mathrm{m}$ and Inchard under the guidance of Prof. Geikie and in company with my colleague of the Irish Survey, Mr. Symes, I take the opportunity offered by Dr. Callaway's paper if expressing my entire concurrence in the interpretation of the structure of the country given by my late chief, whose elaborate and graphic descriptions in the pages of the Qunrterly Journal of the Geological Society (vols. xv. and xvii.) will, I frel sure, never be invalidated.

After seeing the clear infra-position of the limestone to the upper quartzite and-chists first in the section at the Bridge of Ault-Corry near Ullapool, then in the cliffs near Ullapool, next at Inchnadamff and the bead of Loch Assynt, then again in the Forest of Arkle and the hills bordering Loch Stack, where the limestone band is clearly interbedded between the lower and upper quartzites, and this latter as clearly passes under the schists of the interior, it required no further evidence to prove that all these bed. belong to one conformable formation; and that the geological age of the whole group is determined by the fossils discovered by $\mathrm{Mr}$. Charles Peach in the limestone of Durness or Assynt, and naived by the late Mr. Salter. The geological sequence is so clear throughout that region, and so entirely bears out the description given by Murchison and Geikie, that "he who runneth may rrad"; and I bave no hesitation in saying that the evidence that the Millstone Grit overlies the Carboniferous Limestone, and that the New Red Marl overlies the New Red Sandstone is not more clear than that the upper quartzites and schi-ts overlie the Assynt limestone.

I wish to print ont in conclusion that the trough-shaped arrangement of the Iturness limestone and its faulted position, described by Dr. Callaway, has already been described by Murchisun in the Quarterly loumal, vol. xv. Any one visiting the grand tract of country lying between Durness and Loch Maree need have no better guide than the papers I have referred to, and a good geological map. He will find that there is little, if anything, to add to the details and conclusions there given, and were it not that Dr. Callaway's objections seem to find support with soine geologists of more experience than himself, it would not have been necessary to enter a caveat against them.

As reyards the question whether in any part of the Highlands of Scotland except along the western coast the Laurentian (or "pre-Cambrian") rocks reappear, as has been stated or suggested, I do not wish to offer an opinion. As regards the region 
north of the Caledonian Canal, it seems to me that thrs is extremely improbable, as along the two traverses we made-one from Garve to Ullapool, the other from Laxford to Lairg-the prevalent dips are eastward, and the upper quartzites forming the elevations of Ben Dearig and Ben More are of great thickness. One may therefore assume that the Laurentian gneiss (even in the absence of the Cambrian sandstone) is deeply buried beneath these beds and their succeeding schists. The region of the Grampians of Aberdeenshire, on the other hand, is of great extent, and until it has been explored by the officers of the Geological Survey it would be injudicious (as it appears to me) to come to any opinion on the subject. EDWARD HULI

Geological Survey Office, Hu ne Street, Dublin, January I8

\section{Geological Climates}

Having considered the effects of Mr. Wallace's proposed redistribution of land and water, intended to raise the mean annual temperature of Bournemouth $15^{\circ}$ or $20^{\circ} \mathrm{F}$. above its present amount, I now, with your permission, shall say a few words on some minor questions, which have arisen during our discussion of the difficult problem of Geological Climates.

1. Tho Clump of Bamboos at Cooper's Hill Engineering College. - Prof. McLeod has kindly forwarded me a specimen of the foliage of the bambos now growing in his garden, and has promised to send me the fruit when it ripens.

My botanical friends cannot decide its species, with certainty, from the foliage alone, without the seeds, but think that it, probably, is the bamboo called Thamnocalamus Falconeri, formerly called Arundinaria falcata (not Amndinacea) and also called Bambusa gracilis. If this opinion be correct my rejection of its evidence in favour of Cooper's Hill now having the climate of "torrid India" was also correct; for this bamboo is one of the hardiest of the "hardy bamboos" growing in the Himalayas, as high as the limit of perpetual snow, and being exposed, at night and in winter, to extremes of cold, which are never experienced in the British Islands. Whether our summers are hot enongh to ripen its seeds, and fully acclimatise it amongst $u=$, remains to be seen.

It is a suggestive fact that at Fota, in the Cove of Cork, where it grows in clumps 20 feet in circumference, from each of which spring over 400 canes reaching a height of 25 feet; the seeds ripen with difficulty and take a long time to germinate, some two months elapsing before they come through the soil, even in a temperature of $70^{\circ} \mathrm{F}$.

2. The Moreton Bay Pine at Bournemouth.-Mr. William Ingram's letter, stating that an individual of this species, surrounded with "wooded heights" about it, has lived for forty years in Leicestershire, and attained a height of 35 feet, shows what the gardener's skill can accomplish in protecting a sub-tropical tree from the injurious effects of English winters, but throws no light whatever upon the possibility of the Moreton Bay pine living spontaneously in this country.

In order to do so it must ripen its fruit and produce seedlings, which (as I am informed) it cannot possibly do with the moderate heat of our cool summers.

3. Tertiary Climates in England.-Mr. Gardner states, that independently of the evidence afforded by the Moreton Bay pine, the Tertiary fossil plants of the Eocene require an increase of temperature of, at most, $20^{\circ} \mathrm{F}$.

When we add to this that the London clay contains true Crocodiles, true Palms, many species of Nautilus, of Volutes, and large species of Cypraa, we may be certain that $20^{\circ} \mathrm{F}$ increase of temperature is the very minimum required.

The question of importance is, whence did this required heat come from? This is a question of number and magnitude, and not of mere "naturalist talk." This question cannot be settled by redistributions of land and water, nor by repeating continually the assertion that all former causes of change of climate were the same as existing causes, not only in kind, but in degree.

Trinity College, Dublin, January $\mathbf{r}_{4}$ Samuel haughto.

I AGREE with Prof. Haughton in his conclusion that no increase in the quantity of water sent into the Arctic Ocean by currents like the Gulf Stream would make much practical dif. ference in the Arctic climate, though not altogether for his reasons, I think the question of total quantities of heat is irrelevant, and that the extent of glaciation and the distribution of plants and animals are almost exclusively determined by summer temperatures.

Respecting the distribution of plants and animals, I believe this is the general testimony of naturalists, and it is certainly confirmed by Nordenskjöld's observations on the Siberian flora. Respecting glaciation, I rely for proof on the well-known fact that the extent of perpetual snow on mountains - in other words, the height of the snow-line-depends, not on mean temperature, but on summer temperature.

If this is true it shows that no change in the ocean currents would make much difference; for a glance at Dove $s$ isothermal lines for July and January shows that the effect of the Gulf Stream on the temperatures of Europe and Asia and the Arctic Ocean is chiefly confined to wirter. The late Mr. Hopkins, in his well-known paper on changes of climate (Geological Society, December, 185I) estimated that the effect of the Gulf Stream on the July climate of London is null.

Old Forge, Dunmurry, Co. Antrim, January I 7

Prof. Whitney on the Glaciation of British Columbia It must be gratifying to all geologists interested in the western part of America to find that a portion of the general results of the work of the Californian Survey is at length being published under the auspices of the Museum of Comparative Zoology at Harvard College, Prof. Whitney's "Auriferous Gravels of the Sierra Nevada" being now supplemented by the first part of a volume on the "Climatic Changes of Later Geological Times," dealing chiefly with the evidences of glaciation on the Pacific slope. No one will question Prof Whitney's observations and deductions on this subject when he deals with that portion of the region with which he is personally familiar, especially as these are in substantial agreement with the already published facts of Clarence King. The general result arrived at in the areas of Whitney's and King's surveys is that compara. tively only a very small portion of the highest ranges of mountains has ever been covered with glaciers, and that there has never been in this region anything like a northern drift period or a transportation of material in any given direction independent of the present topographical features of the country.

This accords also with the statement published by Prof. Whitney in 1866 (Proc. Col. Acad. Sci. vol. iii. p. 27I) as to the absence of glacial traces of a general character from California, but-as it appears to me unfortunately-a clause was added to this statement embracing in the generalisation the whole north-western extension of the Cordillera region. Now in I866, as Prof. Whitney himself says, almost nothing was definitely known of the coast north of Oregon, and for that portion of it included in the province of British Columbia I have since maintained, as the results of observation, that there is conclusive proof of the occurrence of a period of general glaciation comparable in its effects with that of eastern North America (see Quart. Journ. Geol. Soc. vol. xxxiv. p. 89; Canadian Naturalist, vol. viii. No. 7 ; vol. ix. No. I; also the following Reports of the Geological Survey of Canada, 1875-76, p. 26I I $877-78$, p. I 33 B. ; I $878-79$, p. 89 B.) In summarising and discussing the evidences of glaciation in British Columbia however Prof. Whitney still thinks it necessary to support the correctness of his paper of 1866 . As Prof. Whitney's volume appears to be intended as a general, and, so far as the facts now known go, final review of the glaciation of the Pacific slope, and professes to contain "all that is necessary to set forth in regard to the former glaciation of the western side of the American continent," it may not be amiss to state that in my view the account given of the evidences of glaciation in British Columbia is in some cases insufficient, and that in the interpretation of other points misconceptions as to the nature of the facts have arisen. The tendency of the whole treatment of the subject is to minimise the glacial phenomena of the northern part of the coast and assimilate the conditions there found to those of California, which appear to me to be essentially different. (For a comparison of these see "Travelling Notes on the Surface Geology of the West Coast," Canadian Naturalist, vol. viii. No. 7.)

To criticise minutely the numerous features which seem open to such treatment in the account of this region, with which seven seasons' work in connection with the Boundary Commission and Geological Survey of Canada has rendered me familiar, would require a lengthened article, and would at best be an ungracious task. I will therefore touch on a few salient points only. 